\title{
Utilization of Small Farm Reservoir (SFR) for Upland Agriculture of Bataan, Philippines
}

\author{
Ricson Lorenzo Ines, Jose Paulo Banzon Tuazon, Morrimer Nemesio Daag \\ Department of Agricultural Engineering, Bataan Peninsula State University Abucay Campus, Bataan, Philippines
}

Email address:

rhenz554@yahoo.com (R. L. Ines)

\section{To cite this article:}

Ricson Lorenzo Ines, Jose Paulo Banzon Tuazon, Morrimer Nemesio Daag. Utilization of Small Farm Reservoir (SFR) for Upland Agriculture of Bataan, Philippines. International Journal of Applied Agricultural Sciences. Vol. 4, No. 1, 2018, pp. 1-6. doi: $10.11648 /$ j.ijaas.20180401.11

Received: December 1, 2017; Accepted: December 18, 2017; Published: January 8, 2018

\begin{abstract}
To mitigate and adapt the climate change in the hilly areas, rainwater harvesting will solve the water supply problem in the upland. The main objective of the study was to assess and evaluate the performance of the rainwater impounding reservoir as influenced by hydrological, physical and economic factors specifically demonstrate the benefits in the upland agriculture using harvested water from runoff. There were 20 SFR sites established in the Bataan province. SFR capacity ranges from $126.0 \mathrm{~m}^{3}$ to $3,134.0 \mathrm{~m}^{3}$ of runoff or rainfall water. The average production area was 1.0 hectare. The production without the project was 3.25 to 3.45 tons per hectare while with the SFR were 4.05 to 4.25 tons per hectare. The net income was Php 24,777.49. The Payback Period for SFR was 1.76 years to recover the investment in establishing SFR. Some farmer had no production during the second cropping, for them it was not enough to produce crops, better to put fingerlings.
\end{abstract}

Keywords: Small Farm Reservoir, Climate Change, Mitigate, Rainwater Harvesting, Philippines

\section{Introduction}

Climate change is a significant change in climate in the regions which is result of careless human activities that was observed on common measurements like rainfall, temperature, and air.

To mitigate and adapt the climate change in the hilly areas, rainwater harvesting will solve the water supply problem in the upland. Water storage was used in rainfed-growing areas to provide supplemental irrigation water during rainy season and off-season rice production [1]. Aside from irrigation, water in the small farm reservoir could also be used for small scale fish production, livestock watering and groundwater recharging [2].

Despite of abundance during rainy season, water in the mountains usually goes to rivers down to lakes and oceans when not properly stored or harvested thereby limiting the chance for farmers to store free water from rainfall at any ways when dry season's rice production will come [3].

Establishment of water impounding project in the upper reaches of watershed could be defense against floods at the same time for irrigation, soil erosion control, tapping unused water, pasture improvement for livestock, and future studies of the same field could be possible [4]. Establishment of water impounding reservoir uses the surface runoff to conserve water for productive use and to mitigate climate change. Aside from uses, stored water on the reservoir would use of areas where normally crop production not feasible [5].

The objectives of this study were to analyze the benefits of small farm reservoir in rice production, to demonstrate the benefit of small farm reservoir in crop diversification and fish production, and to analyze the benefit of utilizing the existing small farm reservoir.

The existing small farm reservoir used by common farmers was dugout ponds without any material in the bed of reservoir that reduces stored water losses. A common loss that reduces the volume of stored water was percolation, seepage and evaporation [6]. These water losses might be saved to increase the efficiency of SFR and it would increase the production.

The study was focused on runoff water harvesting and storage for crop production specifically rice and fish production. Included in the study was sedimentation and water management strategies using small farm reservoir. 


\section{Methodology}

\subsection{Conceptual Framework}

The study would document the performance and benefit of small farm reservoir in rice, diversification and fish production. Project starts from communication to proper authority regarding the concept. Instrumentation to the SFR that monitor the input water and discharge (INPUT).

The established reservoir with stored water will optimized in rice and diversified production while raising fish (PROCESS). Development of intervention strategies in optimizing SFR using performance of small farm reservoir and its economic benefits will be the output.

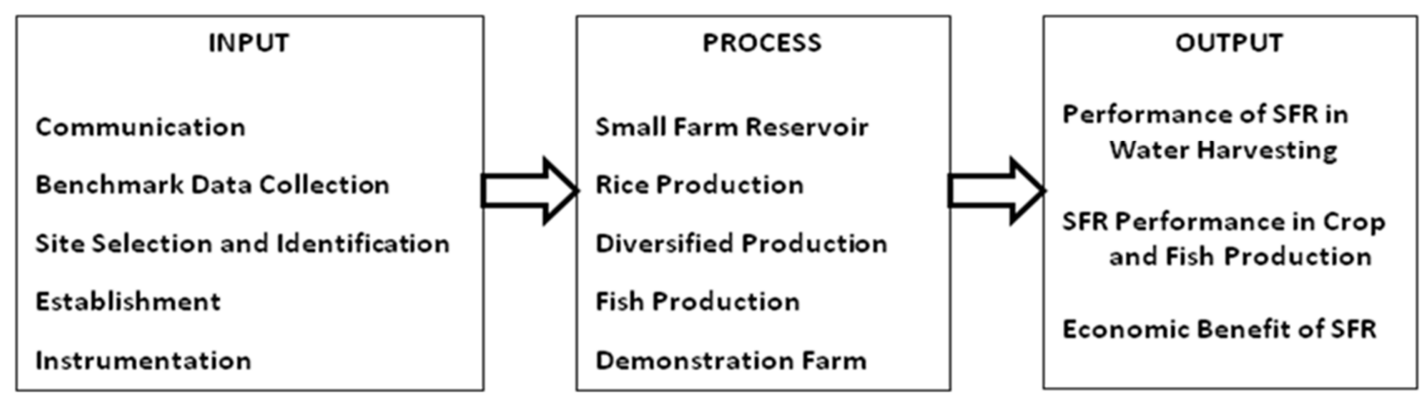

Figure 1. Conceptual framework of the study.

\subsection{Communication, Consultation and Coordination}

Preparation of communication regarding the objectives of the project address to local authority this was start from the province down to barangay level in which the beneficiary was farmers in the upland areas. Together with the DA-LGU and the local authority in the barangay, the farmer cooperator was identified in the barangay level.

\subsection{Benchmark Data Collection}

Site or area selected for the project implementation was rented by means of agricultural supplies given to the farmer cooperator. The identified site was assessed gathering the necessary information that would be use in the analysis such as name of barangay and its local official, location, elevation, soil type and properties, catchment area and service area of the small farm reservoir.

With the use of Geographic Positioning System (GPS), location, elevation, catchment and service area was measured and recorded.

\subsection{Site Selection and Identification}

Farmer Selection - The most farmers selected was the owner of land or the production area and some were tenants for long period that they were allowed to decide on the agricultural development of the area. Most cooperator were at their late ages but capable to do and manage agricultural activities.

Identification of Study Sites - In the province of Bataan, study site was identified depending on the land configuration and status of production. The selected site was rainfed ricebased [7] and that would be the representative of the community both hydrologically, physically and socially. Any strategy developed from this study site was also appropriate for the entire municipality and the province. Site identified has catchment basin areas where runoff flow down to established SFR upon saturation [8].

Topographic Survey - To delineate the catchment area of each study site, topographic survey was conducted. Baseline physical information was gathered from this catchment site. Parameters that were gathered include topography, drainage pattern and slope with the use of GPS including the land use of the selected area [9].

Benchmark Soil Sampling - Benchmark soil samples was collected from each sites and analyzed by the Bureau of Soils for complete physical properties and other necessary data for soil classification purposes following the USDA Soil Taxonomy.

Catchment Area Measurement - The catchment area of every study sites selected were measured using the Geographic Positioning System (GPS). The waterway slope was also measure gathering the elevation of the uppermost area and the lowest portion of the catchment area.

Small Farm Reservoir - Existing SFR was rehabilitated and established instrumentation such as sediment traps and staff gage for monitoring the volume of water stored for any changes in depth.

Downstream of catchment area was established small farm reservoir that contains and store the runoff water. One site was demonstration reservoir for rice, diversification and fish production [10].

\subsection{Establishment of Small Farm Reservoir (SFR)}

Small farm reservoirs were established at the identified site. The existing SFR was evaluated and renovate if there is. Hired heavy equipment was used in the establishment of SFR that might come from the provincial government or from private properties. The SFR depth and area were depending on the catchment area and the land configuration.

\subsection{Instrumentation}

Raingage and Class A Evaporation Pan - To measure rainfall, an automatic raingage with data logger were install at different sites. To monitor the rate of evaporation, a Class A evaporation pan was also installed. The monitoring and measurement was from the start till end of study period. 
Sediment Traps - One sediment trap was constructed. The sediment traps was positioned or installed upstream of the reservoir.

Installation of Staff Gage - Established reservoirs were installed with staff gage to monitor the volume of water stored in the reservoir [11].

\subsection{Data gathering and Collection}

Data gathering, collection and uploading were done once in two weeks for hydrological parameters. Physical factors were observed and recorded before and after the season. Economic parameters such as yield and inputs were collected before and after the production seasons.

Inputs - Cost of materials in the reservoir establishment, rice production expenses, crop diversification inputs including fish production were recorded and monitored.

Gross Income - Total income generated from rice production and crop diversification after harvesting and fish production gross income from the SFR after total harvest were computed.

Net Income - Gross income generated minus the total expenses occurred during establishment and management of small farm reservoir.

Benefit Cost Ratio - The ratio of net income generated in the production to the total expenses occurred during production including services and postharvest operation was estimated.

Internal Rate of Return (IRR) - The number of crop production and fish production season to cope up the expenses in the establishment of small farm reservoir in the upland areas.

\section{Results and Discussion}

\subsection{Farmer Cooperators}

Farmer cooperator were selected based on the following criteria: a) has a rainfed rice production area [12], b) without production after the main crop c) has an space where to established SFR, d) should be land owner or long period tenant and d) willing to be a farmer cooperator of the project (Table 1).

Table 1. Farmer Cooperators information.

\begin{tabular}{|c|c|c|c|}
\hline & COOPERATOR & PROJECT LOCATION/ADDRESS & PRODUCTION AREA (Ha.) \\
\hline 1 & Maximo Guzon & Mabatang, Abucay & 3.0 \\
\hline 2 & Anthony S. Villanueva & Four Lanes, Tuyo, Balanga City & 0.5 \\
\hline 3 & Salvacion Soria & Baseco, Country, Mariveles & 1.25 \\
\hline 4 & Juanito Payao & Baseco, Country, Mariveles & 0.3 \\
\hline 5 & Nilo Pajaroha & Parang II, Samal & 2.5 \\
\hline 6 & Rafael G. Izon & Parang III Ibaba, Samal & 2.5 \\
\hline 8 & Silverio C. Rubiano & Mabatang, Abucay & 0.75 \\
\hline 9 & Sammy B. Rubiano & Mabatang, Abucay & 1.25 \\
\hline 10 & Virgilio DR. Manrique & Mabatang, Abucay & 1.4 \\
\hline 11 & BPSU Abucay & Bangkal, Abucay, Bataan & 0.2 \\
\hline 12 & Michael T. Bugay & Adamson Gugo, Samal & 1.25 \\
\hline 13 & Juanito E. Garcia & Adamson Gugo, Samal & 1.0 \\
\hline 14 & Angelito H. Ortiguerra & Pugad Lawin, San Juan, Samal & 0.75 \\
\hline 15 & Narciso DR. Bugay & Adamson Gugo, Samal & 0.6 \\
\hline 16 & Ricardo V. Suarez & Mambog, Capitangan, Abucay & 0.7 \\
\hline 17 & Armando B. Tamayo & Olipang Liputan, Mabatang, Abucay & 0.3 \\
\hline 18 & Nicanor O. Oliveria & Olipang Liputan, Mabatang, Abucay & 1.5 \\
\hline 19 & Arjel M. Manrique & Olipang Liputan, Mabatang, Abucay & 2.0 \\
\hline 20 & Venancio C. Del Rosario & Barao Daang Bakuran, Mabatang, Abucay & 1.0 \\
\hline
\end{tabular}

\subsection{SFR Location and Characteristics}

Table 2 shows the location, elevation and surface area of established Small Farm Reservoir (SFR). Surface area was ranges from $42.0 \mathrm{~m}^{2}$ to $500.0 \mathrm{~m}^{2}$. Elevation of established small farm reservoir from the sea level ranged from $15.0 \mathrm{~m}$ to $347.0 \mathrm{~m}$. The location of established SFR is within Bataan Province (N 14 ${ }^{0} 26^{\prime}$ E $\left.120^{\circ} 31^{\prime}\right)$.

\subsection{SFR Physical Characteristics and Capacity}

Table 3 shows the dimensions of the established SFR. Top length ranges from $10.0 \mathrm{~m}$ to $55.0 \mathrm{~m}$ and top width ranges from $4.2 \mathrm{~m}$ to $30.0 \mathrm{~m}$. Bottom length ranges from $10.0 \mathrm{~m}$ to $53.0 \mathrm{~m}$ and bottom width ranges from $4.2 \mathrm{~m}$ to $28.0 \mathrm{~m}$.

Based on the dimension of the constructed SFR, it can store rainfall or runoff water ranging from $126.0 \mathrm{~m}^{3}$ to $3,134.0 \mathrm{~m}^{3}$ capacity.

Watershed of the established SFR was measured for the effectiveness to store runoff or rainfall [13]. Table 3 showed the measured dimension of the SFR watershed area. 
Table 2. SFR Location and Physical Characteristics.

\begin{tabular}{|c|c|c|c|c|c|}
\hline & \multirow{2}{*}{ COOPERATOR } & \multirow{2}{*}{ SFR Surface Area $\left(\mathrm{m}^{2}\right)$} & \multicolumn{2}{|l|}{ Location } & \multirow{2}{*}{ Elevation (masl) } \\
\hline & & & North & East & \\
\hline 1 & Maximo Guzon & 500.0 & $14^{0} 44^{\prime} 57.2^{\prime \prime}$ & $120^{0} 31^{\prime} 09.7^{\prime \prime}$ & 33.0 \\
\hline 2 & Anthony S. Villanueva & 144.0 & $14^{0} 26^{\prime} 08.9^{\prime \prime}$ & $120^{0} 31^{\prime} 27.9^{\prime \prime}$ & 15.0 \\
\hline 3 & Salvacion Soria & 284.0 & $14^{0} 26^{\prime} 18.6^{\prime \prime}$ & $120^{0} 31^{\prime} 24.2^{\prime \prime}$ & 88.0 \\
\hline 4 & Juanito Payao & 400.0 & $14^{0} 26^{\prime} 07.4^{\prime \prime}$ & $120^{0} 31^{\prime} 26.6^{\prime \prime}$ & 87.0 \\
\hline 5 & Nilo Pajaroha & 420.0 & $14^{0} 45^{\prime} 45.9^{\prime \prime}$ & $120^{0} 31^{\prime} 29.5^{\prime \prime}$ & 15.0 \\
\hline 6 & Rafael G. Izon & 500.0 & $14^{0} 45^{\prime} 43.2^{\prime \prime}$ & $120^{0} 30^{\prime} 42.5^{\prime \prime}$ & 56.0 \\
\hline 7 & Enrique Maneclang & 500.0 & $14^{0} 41^{\prime} 12.0^{\prime \prime}$ & $120^{0} 15^{\prime} 55.3^{\prime \prime}$ & 15.0 \\
\hline 8 & Silverio C. Rubiano & 500.0 & $14^{0} 44^{\prime} 56.5^{\prime \prime}$ & $120^{0} 31^{\prime} 05.8^{\prime \prime}$ & 21.0 \\
\hline 9 & Sammy B. Rubiano & 420.0 & $14^{0} 44^{\prime} 25.7^{\prime \prime}$ & $120^{0} 26^{\prime} 44.4^{\prime \prime}$ & 19.0 \\
\hline 10 & Virgilio DR. Manrique & 520.0 & $14^{0} 44^{\prime} 38.7^{\prime \prime}$ & $120^{0} 30^{\prime} 46.5^{\prime \prime}$ & 55.0 \\
\hline 11 & BPSU Abucay & 42.0 & $14^{0} 46^{\prime} 11.6^{\prime \prime}$ & $120^{0} 30^{\prime} 01.0^{\prime \prime}$ & 347.0 \\
\hline 12 & Michael T. Bugay & 375.0 & $14^{0} 45^{\prime} 54.2^{\prime \prime}$ & $120^{0} 30^{\prime} 03.6^{\prime \prime}$ & 69.0 \\
\hline 13 & Juanito E. Garcia & 330.0 & $14^{0} 45^{\prime} 54.6^{\prime \prime}$ & $120^{0} 30^{\prime} 0.02^{\prime \prime}$ & 73.0 \\
\hline 14 & Angelito H. Ortiguerra & 400.0 & $14^{0} 46^{\prime} 39.6^{\prime \prime}$ & $120^{0} 30^{\prime} 50.6^{\prime \prime}$ & 44.0 \\
\hline 15 & Narciso DR. Bugay & 200.0 & $14^{0} 45^{\prime} 40.5^{\prime \prime}$ & $120^{\circ} 30^{\prime} 07.0^{\prime \prime}$ & 83.0 \\
\hline 16 & Ricardo V. Suarez & 120.0 & $14^{0} 42^{\prime} 20.7^{\prime \prime}$ & $120^{0} 30^{\prime} 34.3^{\prime \prime}$ & 86.0 \\
\hline 17 & Armando B. Tamayo & 210.0 & $14^{0} 44^{\prime} 37.6^{\prime \prime}$ & $120^{0} 31^{\prime} 11.3^{\prime \prime}$ & 32.0 \\
\hline 18 & Nicanor O. Oliveria & 690.0 & $14^{0} 44^{\prime} 36.4^{\prime \prime}$ & $120^{0} 31^{\prime} 11.5^{\prime \prime}$ & 32.0 \\
\hline 19 & Arjel M. Manrique & 225.0 & $14^{0} 44^{\prime} 36.9^{\prime \prime}$ & $120^{0} 31^{\prime} 06.7^{\prime \prime}$ & 34.0 \\
\hline 20 & Venancio C. Del Rosario & 500.0 & $14^{0} 44^{\prime} 14.4^{\prime \prime}$ & $120^{0} 31^{\prime} 17.6^{\prime \prime}$ & 20.0 \\
\hline
\end{tabular}

\subsection{Sedimentation}

Soil sediments deposited from the SFR bottom was monitored using sediments traps. It was recorded that $11 \mathrm{~cm}$ to $15 \mathrm{~cm}$ depth of sediments every year. The result was 13 years up to 25 years of useful life for the established SFR.

Table 3. Watershed area of SFR.

\begin{tabular}{|c|c|c|c|c|c|c|c|c|c|}
\hline & \multirow{3}{*}{ NAME } & \multirow{3}{*}{ Area (ha) } & \multicolumn{5}{|c|}{ Small Farm Reservoir } & \multirow{3}{*}{$\begin{array}{l}\text { Capacity } \\
\left(\mathbf{m}^{3}\right)\end{array}$} & \multirow{3}{*}{$\begin{array}{l}\text { WATERSHED AREA } \\
\left(\mathrm{m}^{2}\right)\end{array}$} \\
\hline & & & \multicolumn{2}{|c|}{ Length (m) } & \multicolumn{2}{|c|}{ Width (m) } & \multirow{2}{*}{ Depth (m) } & & \\
\hline & & & Top & Bottom & Top & Bottom & & & \\
\hline 1 & Maximo Guzon & 3.0 & 16 & 14 & 12 & 10 & 3.20 & 354.1 & $30 \times 10$ \\
\hline 2 & Anthony S. Villanueva & 0.5 & 20 & 18 & 12 & 10 & 3.20 & 448.0 & $20 \times 10$ \\
\hline 3 & Salvacion Soria & 1.25 & 10 & 9 & 15 & 14 & 2.5 & 230.0 & creek diverted \\
\hline 4 & Juanito Payao & 0.3 & 20 & 18 & 20 & 18 & 2.25 & 543.0 & $25 \times 20$ \\
\hline 5 & Nilo Pajaroha & 2.5 & 21 & 19 & 21 & 19 & 3.25 & 868.7 & $21 \times 70$ \\
\hline 6 & Rafael G. Izon & 2.5 & 34.4 & 31.4 & 19.4 & 16.4 & 3.80 & 1497.6 & $12 \times 34.4$ \\
\hline 7 & Enrique Maneclang & 0.75 & 18 & & 14 & & 1.5 & 126.0 & $18 \times 95$ \\
\hline 8 & Silverio C. Rubiano & 0.75 & 15 & 13 & 15 & 13 & 3.40 & 446.5 & $15 \times 13$ \\
\hline 9 & Sammy B. Rubiano & 1.25 & 24 & 20 & 14 & 10 & 3.5 & 625.3 & $35 \times 50$ \\
\hline 10 & Virgilio DR. Manrique & 1.4 & 10 & 8.5 & 20 & 18 & 3.5 & 411.8 & 4. $75 \mathrm{ha}$ \\
\hline 11 & BPSU Abucay & 0.2 & 10 & & 4.2 & & 3.0 & 126.0 & creek diverted \\
\hline 12 & Michael T. Bugay & 1.25 & 25 & 23 & 15 & 13 & 3.5 & 786.3 & creek diverted \\
\hline 13 & Juanito E. Garcia & 2.0 & 22 & 20 & 12 & 10 & 2.5 & 386.7 & $22 \times 95$ \\
\hline 14 & Angelito H. Ortiguerra & 0.75 & 20 & 18 & 20 & 18 & 4.2 & 1013.6 & surface flow from highway \\
\hline 15 & Narciso DR. Bugay & 0.6 & 17 & 15 & 11 & 9 & 2.8 & 300.5 & $17 \times 10$ \\
\hline 16 & Ricardo V. Suarez & 0.7 & 10 & 8 & 16 & 14 & 3 & 272.0 & $16 \times 10$ \\
\hline 17 & Armando B. Tamayo & 0.3 & 15 & 13 & 15 & 13 & 2.5 & 328.3 & $15 \times 72$ \\
\hline 18 & Nicanor O. Oliveria & 1.5 & 40 & 38 & 30 & 28 & 2 & 1509.3 & $40 \times 72$ \\
\hline 19 & Arjel M. Manrique & 2.0 & 18 & 15 & 18 & 15 & 3.5 & 640.5 & $65 \times 80$ \\
\hline 20 & Venancio Del Rosario & 1.0 & 30 & 30 & 8 & 8 & 4 & 960 & $30 \times 30$ \\
\hline
\end{tabular}

\subsection{Rice Production (Tons) Per Cropping with the Project}

Table 4 showed the seasonal production per area planted by cooperators. It was presented the production without the SFR project and with the established small farm reservoir.

Without the small farm reservoir during the rainy season, 80 percent of the cooperators were produce rice with an average of 3.96 tons per hectare and only three (3) of them had production during second crop with an average production of 3.47 tons per hectare, because they have shallow tube well to supplement irrigation water. Some of them do diversification after the main crop.

The investment cost in the establishment of small farm reservoir was Php 42,755.50 (average). And the average production cost was Php 25, 355.65 per hectare.

With small farm reservoir during the rainy season or the main crop, the average production was 4.16 tons per hectare and 4.30 tons per hectare during the second cropping. The increase in production was due to the availability of water during the time when the crop needs irrigation water. 
The gross income per hectare with the SFR was Php 49,633.00 and net income was Php 24,277.49. In the establishment of SFR, the payback period takes 1.76 years or around 2 years to recover the SFR establishment cost (Table 5).

Table 4. Rice Production (tons) per cropping.

\begin{tabular}{|c|c|c|c|c|c|c|c|c|c|c|c|c|c|}
\hline & \multirow{2}{*}{$\begin{array}{l}\text { COOPERATOR/Actual } \\
\text { Prod'n Area }\end{array}$} & \multicolumn{4}{|l|}{2013} & \multicolumn{4}{|l|}{2014} & \multicolumn{4}{|l|}{2015} \\
\hline & & $1 \mathrm{st}$ & Var & 2nd & Var & $1 \mathrm{st}$ & Var & $2^{\text {nd }}$ & Var & 1st & & 2nd & Var \\
\hline 1 & Maximo Guzon (0.75) & $3.6 *$ & Rc18 & None* & & 4.05 & $\mathrm{R} 40 / \mathrm{R} 42 / \mathrm{F}$ & None & $\mathrm{F}$ & $2.3 * *$ & $\mathrm{C} 130 / \mathrm{F}$ & $\mathrm{D}^{*}$ & $\mathrm{~F}$ \\
\hline 2 & $\begin{array}{l}\text { Anthony S. Villanueva } \\
(0.50)\end{array}$ & $1.0 *$ & & None* & & 1.6 & $\operatorname{Rc} 216$ & None & & 1.5 & $\begin{array}{l}\text { Line } \\
\text { Variety }\end{array}$ & 2.3 & $\begin{array}{l}\text { C130/ } \\
\text { Rc218 }\end{array}$ \\
\hline 3 & Salvacion Soria $(0.75)$ & $2.0 *$ & & None* & & 2.9 & Rc128 & $\begin{array}{l}1.1+ \\
D^{*}\end{array}$ & $\mathrm{RC} 128$ & 3.4 & $\begin{array}{l}\text { Upland } \\
\text { Rice }\end{array}$ & 1.8 & Rc298 \\
\hline 4 & Juanito Payao (0.30) & $1.15 *$ & & $\mathrm{D}^{*}$ & & 1.25 & Rc128 & $\mathrm{D}^{*}$ & Rc128 & 1.4 & Rc128 & $\mathrm{D}^{*}$ & \\
\hline 5 & Nilo Pajaroha (2.0) & $9.5 *$ & & $9.2^{*}$ & & 10.0 & $\mathrm{Rc} 18 / \mathrm{F}$ & 9.6 & $\mathrm{Rc} 218 / \mathrm{F}$ & & Rc218 & & Rc218 \\
\hline 6 & Rafael G. Izon (1.50) & $4.5^{*}$ & & None* & & 7.0 & $\begin{array}{l}\text { C130 } \\
\text { Rc216 }\end{array}$ & None & & 3.0 & C130 & None & \\
\hline 7 & Enrique Maneclang (0.5) & $2.7^{*}$ & & None* & & 3.0 & $\mathrm{Rc} 218 / \mathrm{F}$ & 1.05 & $\mathrm{Rc} 146 / \mathrm{F}$ & 2.2 & Bigante/F & 3.0 & Bigante/F \\
\hline 8 & Silverio C. Rubiano (0.5) & $2.7^{*}$ & & None* & & $0.9 * *$ & & None & & 2.1 & C130 & None & \\
\hline 9 & Sammy B. Rubiano (0.75) & $3.4^{*}$ & & None* & & None & & None & & None & & None & \\
\hline 10 & $\begin{array}{l}\text { Virgilio DR. Manrique } \\
(1.0)\end{array}$ & None* & & None* & & None & $\begin{array}{l}\text { w/1,300 } \\
\text { fingerlings }\end{array}$ & $\mathrm{F}$ & None & $\mathrm{F}$ & $\mathrm{F}$ & $\mathrm{F}$ & None \\
\hline 11 & BPSU Abucay (0.10) & None* & & None* & & $7.125 \mathrm{~kg}+\mathrm{D}$ & $\operatorname{Rc} 23$ & $D^{*}$ & & $\begin{array}{l}10.2 \mathrm{~kg} \\
+\mathrm{D}\end{array}$ & Rc23 & None & \\
\hline 12 & Michael T. Bugay (1.0) & - & & - & & $2.2 *$ & $\mathrm{Rc} 218$ & $0.25 *$ & Rc218 & 2.2 & Rc122 & None & \\
\hline 13 & Juanito E. Garcia (1.0) & - & & - & & $6.5^{*}$ & $\mathrm{Rc} 218$ & None & & $3.0 * *$ & Rc218 & 0.75 & Rc218 \\
\hline 14 & $\begin{array}{l}\text { Angelito H. Ortiguerra } \\
(0.75)\end{array}$ & - & & - & & $3.0^{*}$ & Rc218 & None & & 2.9 & Rc18 & D & $\begin{array}{l}\text { Sweet } \\
\text { F16 }\end{array}$ \\
\hline 15 & Narciso DR. Bugay (0.50) & - & & - & & $2.5^{*}$ & $\operatorname{Rc} 218$ & $2.0^{*}$ & $\operatorname{Rc} 218$ & 2.5 & Rc218 & 1.9 & $\mathrm{Rc} 218$ \\
\hline 16 & Ricardo V. Suarez (0.50) & - & & - & & None* & None & None* & None & None & None & None & None \\
\hline 17 & $\begin{array}{l}\text { Armando B. Tamayo } \\
(0.30)\end{array}$ & - & & - & & - & & - & & $1.25^{*}$ & Rc218 & None & \\
\hline 18 & Nicanor O. Oliveria (1.0) & - & & - & & - & & - & & $4.9^{*}$ & $\begin{array}{l}\text { Rc18, } \\
\text { Rc218 }\end{array}$ & None & \\
\hline 19 & Arjel M. Manrique (1.0) & - & & - & & - & & - & & $4.55^{*}$ & Rc218 & None & \\
\hline 20 & $\begin{array}{l}\text { Venancio C. Del Rosario } \\
(0.50)\end{array}$ & - & & - & & - & & - & & None* & & None & \\
\hline
\end{tabular}

Var - Variety *without project ** reduced area D - diversification

Table 5. Economics of SFR

\begin{tabular}{ll}
\hline Basic Computation & AMOUNT \\
\hline Initial Cost & 43765.00 \\
II. Fixed Cost & \\
a. Depreciation Cost $(10 \%)$ & $4,376.50$ \\
b. Interest on Investment $(10 \%)$ & $4,376.50$ \\
c. Repair and Maintenance $(2 \%)$ & 875.3 \\
d. Tax and Insurance $(2 \%)$ & 875.3 \\
Total Annual Fixed Cost & $10,503.60$ \\
III. Variable Cost & \\
a. Fuel & $1,000.00$ \\
Total Investment Cost & $55,268.60$ \\
IV. Gross Income & $49,633.04$ \\
V. Net Income & $24,277.39$ \\
VI. Return of Investment & $56.81 \%$ \\
VII. Payback Period & $1.76 \mathrm{yrs}$ \\
\hline
\end{tabular}

\section{Summary}

There were 20 SFR sites established in the Bataan province: 6 sites in the Municipality of Samal, 10 sites in the Municipality of Abucay, 1 site in the City of Balanga, 2 sites in the Municipality of Mariveles, and 1 site in the Municipality of Morong. SFR capacity ranges from $126.0 \mathrm{~m}^{3}$ to $3,134.0 \mathrm{~m}^{3}$ of runoff or rainfall water. The average production area was 1.0 hectare. The production without the project was 3.25 to 3.45 tons per hectare while with the SFR was 4.05 to 4.25 tons per hectare. Ten (10) of the famer cooperator were doing the rice-rice cropping pattern while the others were rice-diversfied or rice only without second crop. The net income was Php 24,777.49. The payback period for SFR was 1.76 years to recover the investment in establishing SFR. While the rainfall within 2013 - 2015 years was 2,122.6 $\mathrm{mm}, 2,156.8 \mathrm{~mm}$, and 2,521.1 $\mathrm{mm}$, respectively. 


\section{Conclusion}

Some farmer cooperators do not produce rice or even diversified because of soil texture and structure that could not store water. One farmer do not produce due to personal reason. Some farmer had no production during the second cropping, for them it was not enough to produce crops, better to put fingerlings.

The benefit of SFR were to increase the production annually, rice and diversification. Moreover, utilization of SFR stored water for long period up to its life span including indirect benefit such as fish production, cooling of birds during dry season and even recreation activities.

\section{References}

[1] UNDAN, R. C., J. L. TABAGO, F. D. COLLADO, JR. and B. M. MANABAT. 1992. Design and management of on farm reservoirs for drought alleviation in the Philippines. In: Bhuiyan, S. I. (Ed.), On-Farm Reservoir Systems for Rainfed Ricelands. International Rice Research Institute. Manila, Philippines. http://dspace.irri.org:8080/dspace/bitstream /123456789/328/2/9712200663_content.pdf

[2] SANGATANAN, P. D., R. L. SANGATANAN and T. L. SANGATANAN. 2002. Practical Guide to Soil Conservation. Technology and Livelihood Series. ISBN 971-7471-951. Published by P. D. Sangatanan Marketing, Zarraga, Iloilo, Philippines.

[3] Philippine Council for Agriculture and Resources Research and Development. 1986. The Philippines Recommends for Small Water Impounding Projects. PCARRD Tehnical Bulletin Series No. 61. National Science and Technology Authority and the Bureau of Soils. Los Baños, Laguna.

[4] MONTE, R. A. and R. G. PALIS. 1987. Physical and economic evaluation of selected water impounding project. Soil and Water Technical Bulletin Vol. 1, Annual Issue 1987, Department of Agriculture- Bureau of Soil and Water Management, Taft Avenue, Manila. Pp. 169-197.

[5] MOYA, T. B., W. C. DELA VIÑA and S. I. BHUIYAN. 1986. Potential of on-farm reservoir use for increasing productivity of rainfed rice areas: The Philippine Case. Modified version of the paper originally published in Agricultural Management.
In: Bhuiyan, S. I. (Ed.), On-Farm Reservoir Systems for Rainfed Ricelands. International Rice Research Institute. Manila, Philippines.

http://dspace.irri.org:8080/dspace/bitstream/ 123456789/328/2 /9712200663_content.pdf

[6] SCHWAB, G. O., D. D. FANGMEIER, W. J. ELLIOT and R. K. FREVERT, 1993. Soil and Water Conservation Engineering. Fourth Edition. John-Wiley Sons, Inc., New York.

[7] KHUSH, G. S. 1997. Soil Origin, dispersal, cultivation and variation of rice. Plant Molecular Biology, 35: 25-34.

[8] Philippine Council for Agriculture and Resources Research and Development. 1998. Philippine Recommends for Irrigation Management for Crop Diversification. PCARRD Technical Bulletin Series No. 83. National Science and Technology Authority and the Bureau of Soils. Los Baños, Laguna, Philippines.

[9] MAGLinAO, A. R., E. C. VERGARA, E. M. BELEN and M. S. JOVELLANOS. 1994. Philippine national program on small farm reservoir: organization, experiences and challenges. In: Bhuiyan, S. I. (Ed.), On-Farm Reservoir Systems for Rainfed Ricelands. International Rice Research Institute. Manila, Philippines. http://dspace.irri.org:8080 /dspace/bitstream/ 123456789/328/2 /9712200663_content.pdf

[10] UNGER, P. W. and T. A. HOWELL. 1999. Agricultural water conservation - A global perspective. Water Use in Crop Production by M. B. Kirkham. Journal of Crop Production. Volume 2, No. 2 (\#4). 1999.

[11] LENKA, D. 1991. Irrigation and Drainage, First Edition.

[12] DE GUZMAN, E. 2013. A GIS-Aided Decision Support System for Small Farm Reservoir. Unpublished masteral thesis in Agricultural Engineering, Institute of Graduate Studies, Central Luzon State University, Nueva Ecija, Philippines.

[13] GUERRA, L. C., P. G. WATSON and S. I. BHUIYAN. 1990. Hydrological characteristics of on-farm reservoirs (OFRs) in rainfed rice growing areas. Modified version of the paper originally published in Agricultural Water Management. In: Bhuiyan, S. I. (Ed.), On-Farm Reservoir Systems for Rainfed Ricelands. International Rice Research Institute. Manila, Philippines. http://dspace.irri.org:8080/dspace/bitstream/ 123456789/328/2/9712200663 content.pdf 